\title{
دور حامض اللايبوتكوك المنقى جزئيا من بكتريا E.faecalis المعزولة محليا في الالتصاق
}

\author{
خمائل لطفي شاكر، مي طالب فليح و لينة عبد الكريم \\ قسم علوم الحياة، جامعة بغداد، كلية العلوم.
}

الخلاصة

اختبرت قابلية العزلة E.faecalis U12 في الالتصاق في الخلايا الطلائية البولية، فتبين ان البكتيريا تلتصق بمعدل 81.25

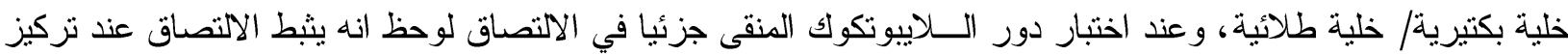

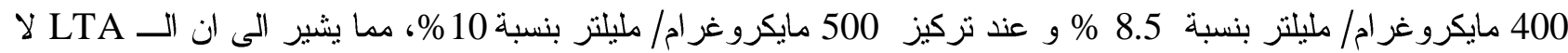

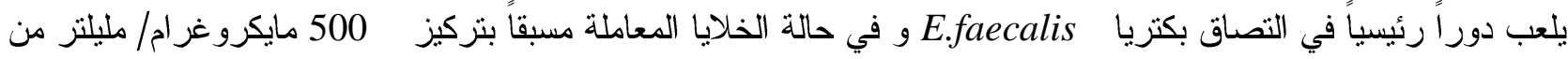
dLTA لم يتم الحصول على ابي فعل تثبيطي للالتصاق ، مما يشير الى دور الجزء الثحمي للـ LTA في عملية الالتصاق. الكلمات المفتاحية: الاللتصاق، حامض اللاييوتكوك، طلائية، العزلة U12.

الارتباط بأغشية الانسجة و تحسين التفاعل الالتهابي الموضعي السام [8،9]. لهذا هدفت هذه الدر اسة الى دراسة دور الــTA المنقى جزئيا في التصاق بكتريا Enterococcus faecalis

$$
\text { ل للانسان. }
$$

$$
\text { المواد وطر ائق العمل }
$$

حامض اللايبوتكوك (LTA) المنقى جزئيا استعمل الــ LTA المستخلص و المنقى جزئيا من

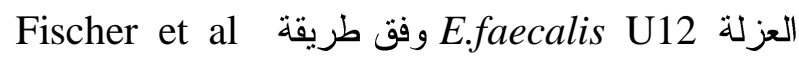

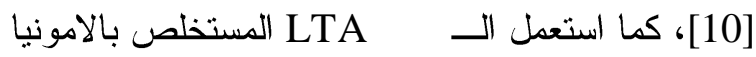
وفق طريقة (dLTA) عليه من خلال در اسة سابقة.

أختبار التصاق بكتريا E. faecalis في الخلايا الطلايةية البولية للانسان

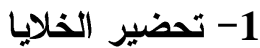
- ت تحضير خلايا البكتيريا نشطت العزلة E.faecalis U12 على اكار تربتك صويا لمدة 24 ساعة، ثم نقلت مستعمرتان الى مرق تربتلك صويا و حضنت عند درجة 37 م لمدة 18 ساعة، نبذت الخلايا بجهاز الطرد المركزي بسرعة 3000 دورة/دقيقة

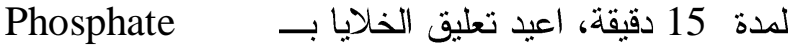
Buffer Solution ذبي الرقم الهيدروجيني 7.2 و أعيدت عملية النبذ مرتين، ثم علقت الخلايا بـ PBS، ضبط عدد

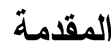
يعرف الــ Lipoteichoic acid بأنه حامض التكويك

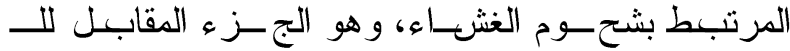

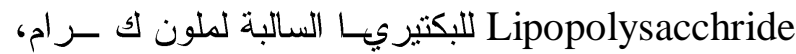
المكــون م-ن بوليمرمـن تلكـــار وحـــات -Glycerol مرتبط عرضيـا بوساطـة أصـرة 3-1 Phosphate Phosphdiester، يقترب LTA اللمكورات المعوية بما فيه الكفاية من سطح الخلية حتى نهايتها البعيدة ليعمل كمستضد لهذه المجموعة المصلية (مجموعة D)، اذ يحفز تكوين

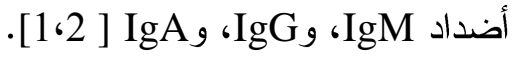
يعد الـ LTA عاملا " محفز ا "للاستجابة الالتهابية

لللمضيف و من ثم دوره في الصدمة الأنتانية للبكتيريا

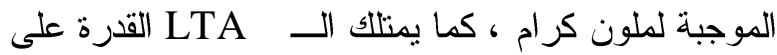

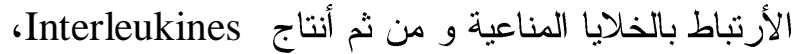
(IFN $\gamma$ g و TNF $\alpha$ و Nitric Oxide الـ أتأزريا مع البيتيدو كلايكان كعامل محفز للاستجابة الالتهابية للمضيف ، و ينتج عنها صدمة و فنشل لئل

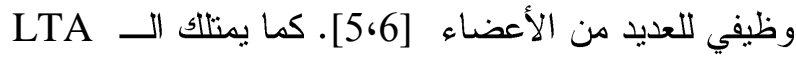
القدرة على تتشيط المتمم بالطريقه التقليدية و الطريقة البديلة [7].

يمتاز الــ LTA بألفته العالية تجاه أغشية الخلايا، أذ يرتبط الــ LTA بمختلف خلايا اللبائن بوساطة الجزء

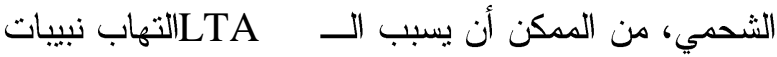
الكلية، و التهاب المفاصل في الحيو انات المختبرية بوساطة 
دور الـ LTA في التصاق بكتريا E.faecalis بالخلايا الطلائية البولية للانسان أتبعت طريقة[8 Ofek et al]

حضرت الخلايا الطلائية للانسان بتركيز (10 (10 )

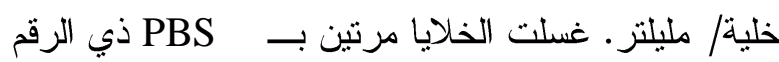
الهيدروجيني 7.2 بنبذها بسر عة 1500 دورة/ دقيقه لمدة 5

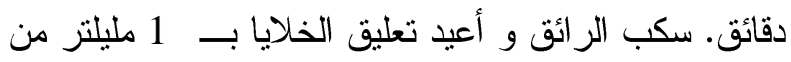

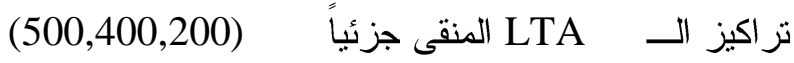

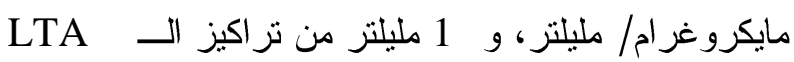

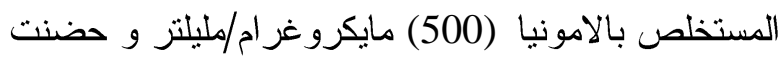
الانابيب عند درجة 37 م، لمدة 30 دقيقة. غسلت مرتين بـ ب دي الرقم الهيدروجيني 7.2، أعيد تعليق الخلايا بـ 1 مليلتز من PBS، ثم اضيف حجم مساوي من العالق

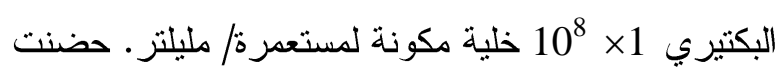

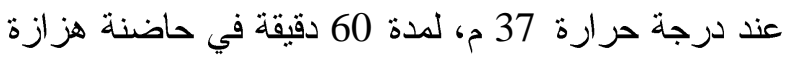
بسرعة 70 دورة/دقيقة. نبذ بسرعة 1500 دورة:/دقيقة لمدة فئه 5 دقائق، و حضرت شريحة زجاجية (مكرران) بنشر القطرة المتنقية على الثريحة الزجاجية برقة (للحفاظ على رهن الخلايا و عدم تكسير ها) ثم تركت لتجف في الهواء. ثبت لته

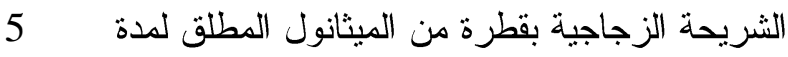

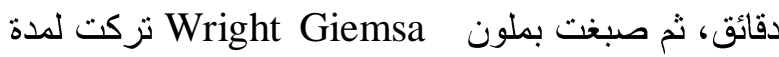
ساعة ثم غسلت، نركت لتجف، ثم فحصت بالمجهر بمرن الضوئي بقوة تكبير 100x باستعمال الزيت، سجلت النتائج بحساب عدد البكتريا الملتصقة بـ 40 خلية طلائية [12].

\section{النتائج و المناقشة} أختبار التصاق لبلانسان أختيرت العزلةE.faecalis U12 لاجر اء أختبار الالتصاق

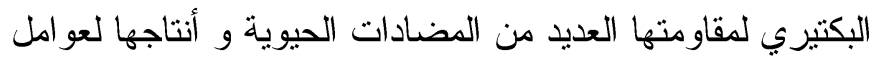

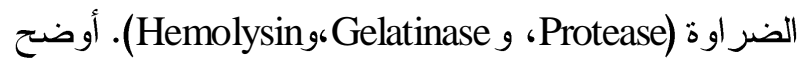
Guzman و جماعته(13) ان عزلات الادرار الممرضة تلتصق ونق

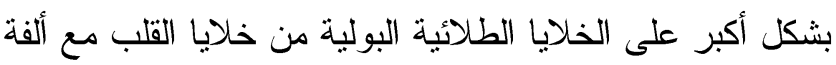

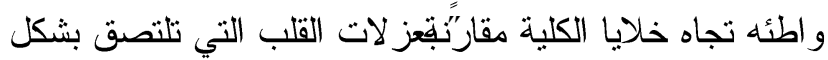
أكبر على خلايا القلب من خلايا الادرار مع ألفة ايضاً واطئه تجاه

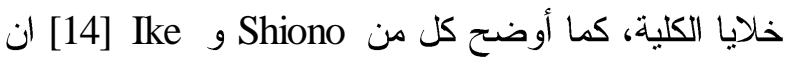

الخلايا الى ( 1 x $10^{8}$ ) خلية مكونة لمستعمرة/ مليلتر

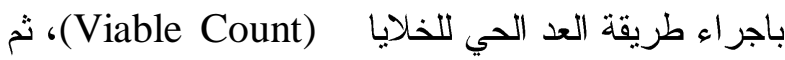
سحب العالق عدة مرات بوساطة محقنة ذات ابرة gauge لغرض تفكيك السلاسل.

\section{- تحضير الخلايا الطلاية البولية}

Gauzman et al و أعتمد ت طريقة Eden et al [12

•جمعت عينة ادرار صباحية من نساء سليمات (مع معات

التأكد من عدم وجود حالة التهاب للمجاري البولية) نبذت الخلايا الطلائية بسرعة 1500 دورة دودة دقيقة لمدة

5

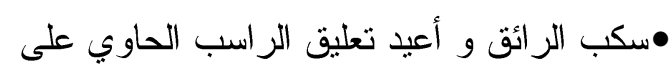

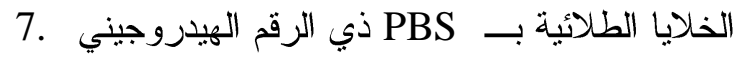
و رجت رجاً خفيفاً ثم أعبدت عملية النبذ (3-4) مرات

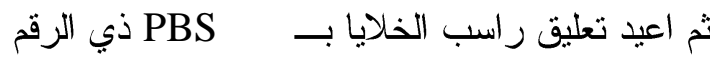

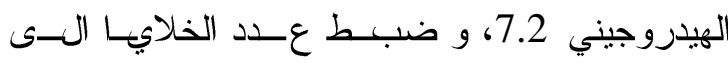

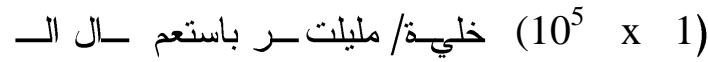

.Hemocytometer

$$
\text { 2- أختبار الالتصاق البكتيري }
$$

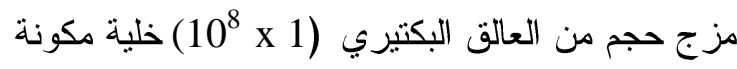
لمستعمرة / مليلتر مع حجم مساو من عالق الخلايا الطلائية

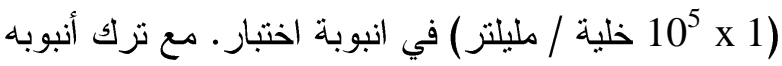
بدون أضافة العالق البكتيري كسبطره و حضنت البنت الانابيب

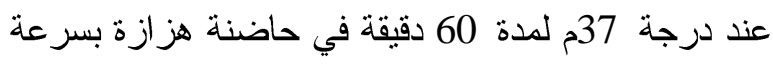
70 دورة/دقيقة. نبذ العالق بسرعة 1500 دورة//دقيقة لمدة

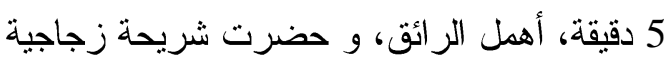
(مكرران) بنشر القطرة المتبقية على الثريحة الزجاجية

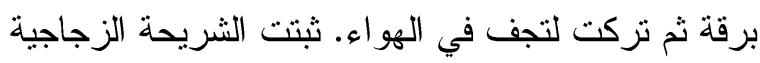

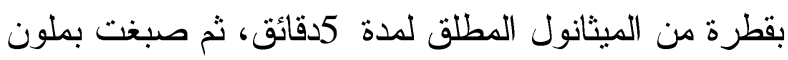
Wright Giemsa

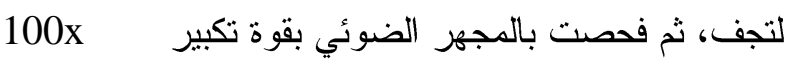
باستعمال الزيت، سجلت النتائج بحساب عدد البكتريا

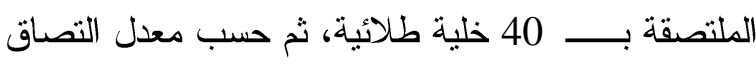
البكتريا/ خلية طلائية [12]. 


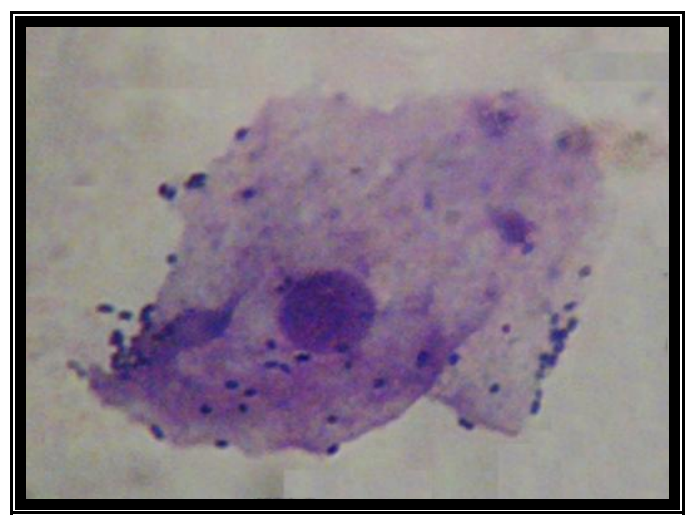

الثكل (3) التصاق بكتريا E.faecalis في الخلايا الطلاية البولية المعاملة مسبقاً بتركيز 500 مايكروغرام LTA / مليلتر. قوة تكبير (100X).

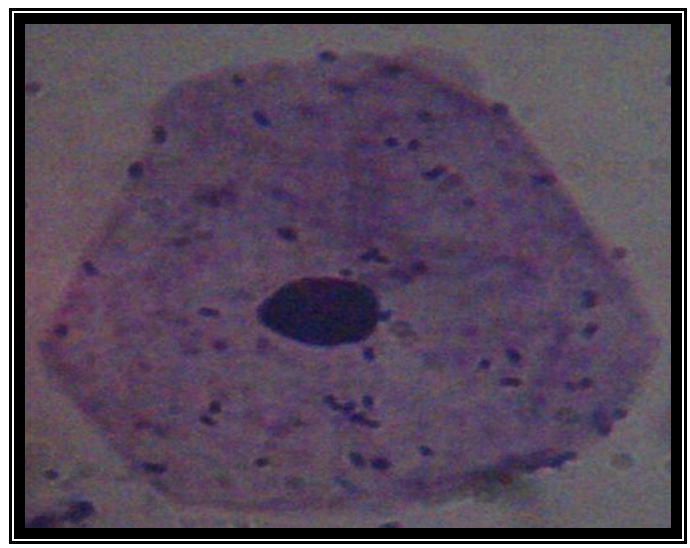

الثكل (4) بكتريا E.faecalis في الخلايا الطلائة البولية المعاملة مسبقاً بـ 500 مايكروغر ام dLTA / مليلتر.

$$
\text { قوة تكبير (100X). }
$$

يلاحظ ان الــLA عامل التصاق للعديد من البكتريا، اذ

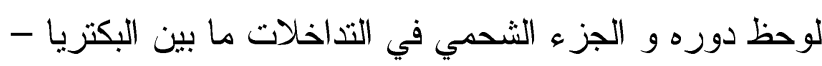
المضيف و التي تتطلب الفة تجاللاغشية و بالتالي دوره في الضراوة لمختلف البكتريا الممرضة [8]. اذ من الممكن ان

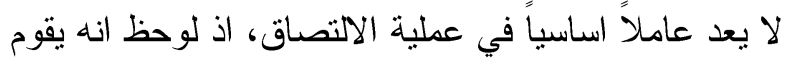

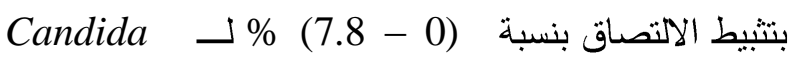
albicans

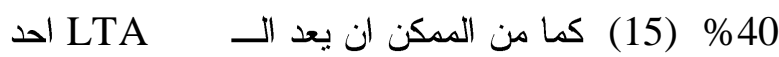

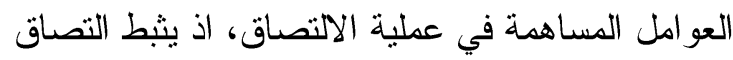
Group B Streptococci 400 مايكروغرام LTA / ملبلتز و بنسبة 76.8\% بنسية

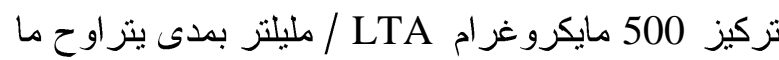

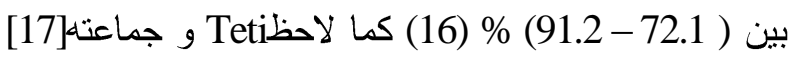
ان مستخلص الـ LTA لبكتريا Saprophyticus يثبط
عزلات الادرار الممرضة تلتصق بخلايا الادرار و خلايا الامعاء في حين عزلات الخروج من اشخاص اصحاء لا تلتصق بخلايا الادرار. تم التاكد من عدم وجود بكتريا ملتصقة في الخلايا

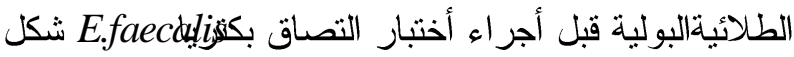
(1)، في حالة وجود بكتريا ملتصقة في الخلايا يتم أهمال الادرار .

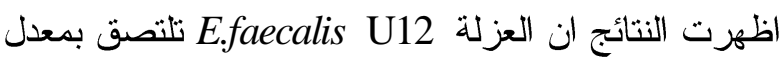
81.25 خلية بكتيرية / خلية طلائية و الثن(ل).
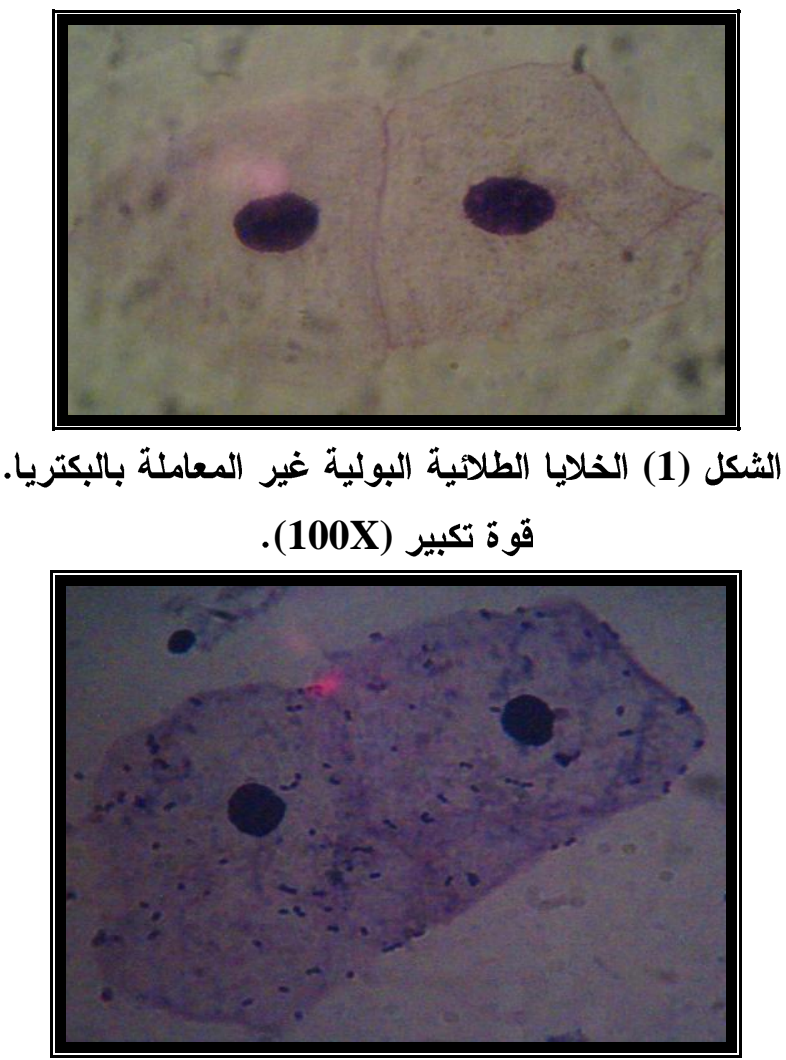

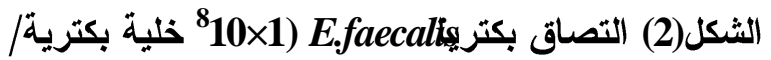

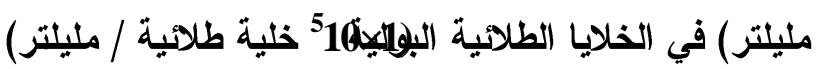

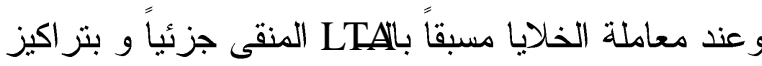

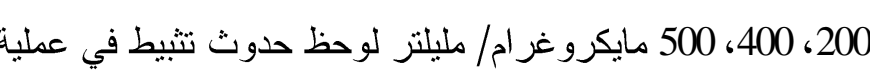

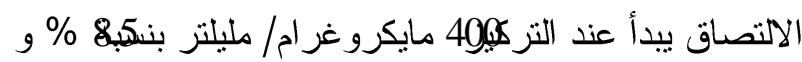

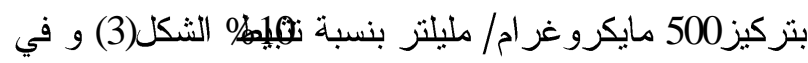

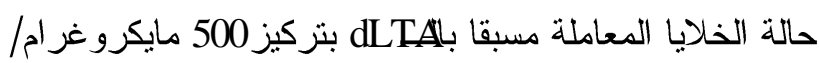
مليلتر لم يتم الحصول على اي تأثير تثبيطي لالتصاق بكتريا E.faecalis 


\section{References:}

[1] Wicken A.J. and Knox K.W. Lipoteichoic Acid: A New Class of Bacterial Antigen . Science. 187:1161-1167. (1975).

[2] Simpson W.A.; Ofec I.; and Beachey E.H. Binding of Streptococcal Lipoteichoic Acid to the Fatty Acid Binding Sites on Serum Albumin.J.Bio.Chem. 225 (13):6092-6097. (1980).

[3] Morath S.; Geyer A.; Spreitzer I.; Hermann C. and Hartung T.. Structural Decomposition and Heterogenecity of Commerical Lipoteichoic Acid Preparations. Infect.Immun. 70(2):938944. (2002)

[4] Amersfoort E.S.V.; Van Berkel T.J.C. and Kuiper J. Receptors, Mediators and Mechanisims Involved in Bacterial Sepsis and Septic Shock. Clin. Microbiol. Rev. 16(3): 379-414. (2003).

[5] Heumann D.; Barras C.; Severin A.; Glauser M.P. and Tomasz A.. GramPositive Cell Wall Stimulate Synthesis of Tumer Necrosis Factor Alpha and Interleukin- 6 by Human Monocytes. Infect. Immun. 62(7): 2715-2721. (1994).

[6] Leemans J.C.; Heikens M.; Kessel K.P.M.; Florquin S. and Poll T.V.D. . Lipoteichoic Acids and Peptidoglycan from Staphylococcusaureus Synerginistically Induce Neutrophil Influx in to the Lung of Mice. Clin.Diag.Lab. Immun. 10 (5):950953. (2003).

[7] Fiedel B.A. and Jackson R.W.. تداخل الجزء الثحمي مع الطبقة الثحمية الثائية للخلايا عن طريق Immunogenicity of a Purified and CarrierComplex Streptococcal Lipoteichoic Acid. Infect.Immun. 13 (6): 1585-1590. (1976).

[8] Ofek I. Beachey; E.H.; Jefferson W. and Campbell G.L.. Cell Membrane -Binding Properties of Group A Streptococcal Lipoteichoic Acid. J.Exp.Med. 141:9901002. (1975).

[9] Joyanes P.; Pascual A.; Martinez-Martinez L.; Hevia A. and Perea E.J.. In vitro Adherence of Enterococcus faecalis and Enterococcus faecium to Urinary Catheters. Eur.J.Clin .Microbiol. Infect.Dis. 19(2): 124-127. (2000).

[10] Fischer W.; Koch H.U. and Haas K.. Improved Preparation of Lipoteichoic Acid .Eur .J .Biochem. 17 :523-530 . (1983).

[11] Ofek I.; Beachey E.H.; Jefferson W. and Campbell G.L.. Cell Membrane -Binding
الالنصاق في الخلايا الطلائية البولية بنسبة تتراوح ما بين

$$
\text { (67.9-66.8) عند تركيز100مايكروغر ام/ مليلتز . }
$$

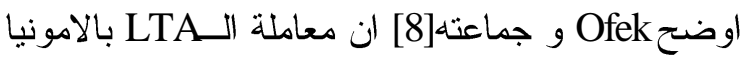

تسبب تحرير الثحوم المرتبطة بوساطة الاصرة الاستيرعين

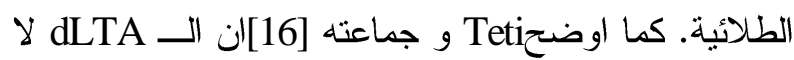

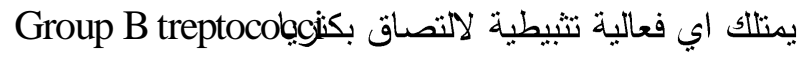

في الخلايا الطلائية، امالمhugh و جماعته [15] بين ان الــ

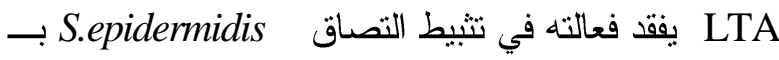

Fibrin-platelet clot

يساهم الـLTA في عملية الالتصاق بمختلف خلايا اللبائن

بوساطة الجزء الثحمي أما بوساطة مستقبلات خاصة أو بزيادة

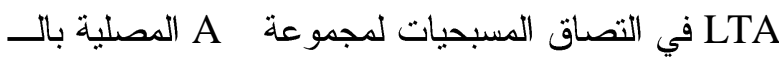

Fibronectin

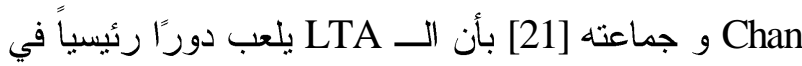

التصاق بكتريا Lactobacillus في خلايا الادرار بوساطة

مستقبلات خاصة تختلف عن تلك التي تستغل بوساطة

الممرضات، أذ يرتبط الــTA بسطح الخلايا و يمنع أرتباط

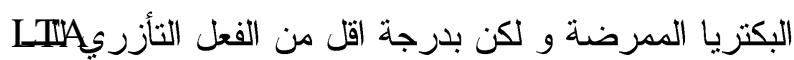

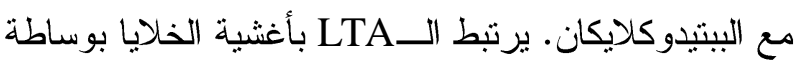

البوليمر ، و ان هذه الشحوم مسؤولة عن الارتيلطنتلف الخلايا

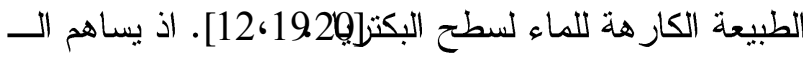

تشكيل أصرة كار هة للماء مع الجزء الشهلهي].

تشير نسبة التثبيط الواطئة للالتصاق التتي الحصول عليها

عند معاملة الخلايا باللاLLT الى ان الـLTA يعد احد العوامل

المساهمة في عملية الالتصاق بكترين.faecalif و ليس كعامل

التصاق رئيسي في الخلايا الطلائية البولية. اذ اشار العديد من لئل

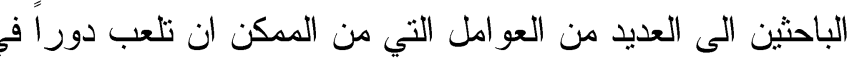

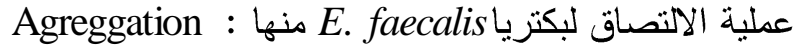

substance و و Enterococcal surface proteins، اذ اوضح Toledo-Arana الاولي و تكوين biofilm لعز لات E. faecalis على الاسطح الحية، و عامل كاربو هيدر اتي D-mannose-D-glucose في عزلات الادرار و D-galactose-D-fructose في عزلات القلب[23]. 
johnsonii La1 to Human Enterocyte-Like Caco-2 Cells. Appel. Enviro. Microbiol. 65(3):1071-1077. (1999).

[21] Chan R.C.Y.; Reid G.; Irvin R.T.; Bruce A.W. and Costerton J.W.. Competitive Exclusion of Uropathogens from Human Uroepithelial Cells by Lactobacillus Whole Cells and CellWall Fragments. Infect. Immun. 47(1):84-89. (1985).

[22] Toledo-Arana A.; Valle J.; Solano C.; Arrizubieta M.J.; Cucarella C.; Lamata M.; Amorena B.; Leiva J.; Penades J.R. and Lasa I..The Enterococcal Surface Protein, ESP, Is Involved in Enterococcus faecalis Biofilm Formation. Appl.Enviro.Microbiol. 67(10): 4538-4545. (2001).

[23] Guzman C.A.; Pruzzo C.; Plate M.; Guardati M.C. and Calegari L.. Serum Dependent Expression of Enterococcus faecalis adhesions Involved in the Colonization of Heart cells. Microb.Pathog. 11(6):399-409. (1991).

\begin{abstract}
The isolate E.faecalis U12 was tested for adhesion to Uroepithelial cells, the bacteria adhere in average of 81.25 (bacterial cell/ epithelial cell) .When the role of partial purified LTA was tested The adherence was inhibited by using $400 \mu \mathrm{g} / \mathrm{ml}$ LTA and $500 \mu \mathrm{g}$ $/ \mathrm{ml}$ LTA in a percentage of $8.5 \%$ and $10 \%$ respectively, these results refered to the secondary role of LTA in the adherence of E.faecalis. While it could not inhibit the adherence in $500 \mu \mathrm{g} / \mathrm{ml}$ dLTA, this refered to the role of lipid part of LTA in the adherence.
\end{abstract}

Properties of Group A Streptococcal Lipoteichoic Acid. J.Exp.Med.141:9901002. (1975).

[12] Eden C.S.; Eriksson B., and Hanson. Adhesion of Escherichia coli to Human Uroiepithelial cells In vitro.Infect.Immun . 18(3): 767-774. (1977).

[13] Guzman C.A.; Pruzzo C.; Lipira G. and Calegari L. Role of Adherence in Pathogenesis of Enterococcus faecalis Urinary Tract Infection and Endocarditis .Infect.Immun. 57(6):1834-1838. (1989).

[14] Shiono A. and Ike Y. Isolation of Enterococcus faecalis Clinical Isolates That Efficiently Adhere to Human Bladder Carcinoma T24 Cells and Inhibition of Adhesion by Fibronectin and Trypsin Treatment. Infect. Immun.67(4):1585-1592. (1999)

[15] Chugh T.D.; Burns G.J.; Shuhaiber H.J. and Bahr G.M.. .Adherance of Staohylococcus epidermidis to FibrinPlatelet Clots In Vitro Mediated by Lipoteichoic Acid .Infect.Immun. 58(2): 315-319. (1990).

[16] Teti G.; Tomasello F.; Chiofalo M.S.; Orefici G. and Mastroeni P. .Adherance of Group BStreptococci to Adult and Neonatal Epithelial Cells Mediated by Lipoteichoic Acid. Infect.Immun. 55(12):3057-3064. (1987).

[17] Teti G.; Chiofalo M.S.; Tomasello F.; Fava C. and Mastroeni P. Mediation of Staphylococcus saprophyticus Adherence to Uroepithelial Cells by Lipoteichoic Acid. Infect.Immun. 55(3):839-842. (1987).

[18] Nealon T.J. and Mattingly S.J. Role of Cellular Lipoteichoic Acid in Mediating Adherance of Serotype III Strains of Group B Streptococci to Human Embryonic, Fetal,and Adult Epithelial Cells. Infect.Immun .43(2):523-530. (1984).

[19] Gibbons R.J. and Houte J.V.. Selective Bacterial Adherance to Oral Epithelial Surface and Its Role as an Ecological Determinant. Infect. Immun. 3 (4):567-573. (1971).

[20] Granato D.; Perotti F.; Masserey I.; Rouvet M.; Golliard M.; Servin A. and Brassart D..Cell Surface-Associated Lipoteichoic Acid Acts as an Adhesion Factor for Attachment of Lactobacillus 